\title{
Synthesis and Preliminary Antimicrobial Activity of New Schiff Bases of Pyrido [1,2-a] Pyrimidine Derivatives with Certain Amino Acids
}

\author{
Shakir M Alwan ${ }^{1 *}$, Jaafar Abdul-Sahib Al-Kaabi²
}

${ }^{1}$ Pharmaceutical chemistry department, College of Pharmacy, University of Baghdad, Bab Al-Moadham, P.O. Box 14026, Baghdad, Iraq

${ }^{2}$ College of pharmacy, University of Messan, Messan, Iraq

\begin{abstract}
Pyrido [1,2-a] pyrimidine ring structure is one of the most interesting heterocycles in drug design and its derivatives have various potential pharmacological activities. An interesting approach of synthesizing a new series of pyridopyrimidine derivatives containing Schiff bases of certain amino acids, as privileged moieties of expected high potential in the field of antibacterial and antitumor agents, were investigated that may provide a synergistic model. The new derivatives 1-6 were synthesized by reacting 3-formyl-2H-pyrido [1, 2-a] pyrimidine-2, 4 (3H)-dione $1 \mathrm{~b}$ with glycine, alanine, glutamic acid, histidine, tryptophan or leucine in methanol under reflux using glacial acetic acid as catalyst. The chemical structures of the new compounds and their intermediates (1-6, 1a and $1 \mathrm{~b}$ ) were characterized, identified and confirmed by spectral analysis (IR, $\left.{ }^{1} \mathrm{H}-\mathrm{NMR}\right)$ and elemental microanalysis $(\mathrm{CHN})$ and the results were within the acceptable limits. Disc-diffusion method was used to evaluate the antimicrobial activities of the newly synthesized compounds of interest 1-6, using Pseudomonas aurginosa, Staphylococcus aurueus, Bacillus subtilus, Candida albicans and Escherichia coli. The synthesized compounds 1-6 showed variable antibacterial activities ranged between good to moderately active, when compared with standards (amoxicillin and ceftriaxone). Compounds 4-6 also showed antifungal activities. However, compounds 5 and 6 are the most potent and have promising results. Compound 6 showed a good activity against all bacterial strains and fungi tested, while compound 5 showed the highest activity against Pseudomonas auroginosa. This approach has afforded the synthesis of new pyrido-pyrimidine derivatives containing Schiff bases of certain amino acids of reasonable and promising antibacterial activities.
\end{abstract}

\section{Keywords: Pyridopyrimidine; Schiff bases; Amino acids}

\section{Introduction}

Pyrido [1, 2-a] pyrimidine ring structure is one of the most interesting heterocycles in drug design [1], and compounds containing this moiety have various pharmacological activities [2]. This structural pattern is present in the known psychotropic agents risperidone [3] paliperidone [4], human leukocyte elastase inhibitor (SSR69071) [5], antiallergic agent ramastine [6], and the antioxidants 2-arylpyrido [1, 2-a] pyrimidin-4-ones [7]. Pyrimidines exhibit potential antibacterial [8], antiviral, [9] antitumor [10], anti-HIV [11], antinociceptive [12] activities and are extensively used in neurology, particularly in the treatment of neurodegenerative disorders, such as, Parkinson's disease [13], anti-anxiety disorders [14] and anti-depression cases [15].

Schiff bases have been shown to exhibit a wide range of biological activities including antimicrobial [16], anti-inflammatory and analgesic [17], anti-tubercular [18], antioxidant [19], antiviral and antifungal [20] and anticancer activities [21]. Schiff bases of 2-chloro3-formyl-4-oxo-4H-pyrido [1, 2-a] pyrimidine with cyclic hydrazides were synthesized and tested for their antihypertensive and MAOinhibitory activities [16]. The antibacterial and antifungal activities of Schiff bases of amino acids derived from the reaction of 2-hydroxy1-naphthaldehyde with glycine, alanine, phenylalanine, histidine and tryptophan were reasonably potent [17]. Three new Schiff bases of indole-3-carboxaldehyde with glycine, alanine and valine have indicated better activities against S. aureus, E. coli and B. polymyxa than C. albicans [18].

In view of the stated pharmacological properties of the pyridopyrimidine derivatives and Schiff bases, a new series of pyridopyrimidine derivatives containing Schiff bases of certain amino acids as privileged moieties of expected high potential in the field of antibacterial and antitumor agents were investigated.

\section{Materials and Methods}

\section{Chemicals}

2H-pyrido [1,2-a] pyrimidine-2,4- $(3 \mathrm{H})$ dione, 1a was synthesized by reacting 2 -amino pyridine and diethylmalonate in ethanol at 160 $200^{\circ} \mathrm{C}$ for $4 \mathrm{hrs}$ with continuous removal of ethanol by distillation [19] as illustrated in scheme 1 . The corresponding aldehyde $1 \mathrm{~b}, 3$-formyl-2Hpyrido $[1,2-\mathrm{a}]$ pyrimidine-2,4-(3H) dione, was synthesized by reacting compound la with Phosphoryl chloride and N, N-dimethylformamide [20], as shown in scheme 1 . The Schiff bases 1-6 were synthesized by reacting 3 -formyl-2H-pyrido [1,2-a] pyrimidine-2,4- $(3 \mathrm{H})$ dione $1 \mathrm{~b}$ with either glycine, alanine, leucine, glutamic acid, histidine or tryptophan in methanol in the presence of a catalytic amount of glacial acetic acid $(0.5 \mathrm{~mL})$ under reflux [21], as outlined in scheme 1 . The amino acids, 2-aminopyridine and diethylmalonate were purchased from Himedia, N,N-dimethylformamide and phosphoryl chloride were obtained from Fluka AG. Petroleum ether (40-60) was from BDH. All other chemicals and solvents were of analar grade.

\section{Bacteria}

The following pathogenic bacteria and fungi are used to evaluate the antimicrobial activity of the newly synthesized compounds. Pseudomonas aurginosa (P. auroginosa, ATCC 27853), Staphylococcus aurueus (S. aurueus, ATCC 25923), Bacillus subtilus (B. subtilus, ATCC 6633), Candida albicans (C. albicans, isolated from a local hospital and was inoculated on a chocolate agar plate and grown at $37^{\circ} \mathrm{C}$ for $48 \mathrm{~h}$ ) and Escherichia coli (E. coli, ATCC 29522) cultured on Mueller Hinton agar.

*Corresponding author: Shakir M Alwan, Pharmaceutical chemistry department College of Pharmacy, University of Baghdad, Bab Al-Moadham, P.O. Box 14026 , Baghdad, Iraq, Tel: +9647902518888; E-mail: shakmawales@yahoo.co.uk

Received July 08, 2014; Accepted August 20, 2014; Published August 22, 2014

Citation: Alwan SM, Al-Kaabi JAS, Hashim RMM (2014) Synthesis and Preliminary Antimicrobial Activity of New Schiff Bases of Pyrido [1,2-a] Pyrimidine Derivatives with Certain Amino Acids. Med chem 4: 635-639. doi:10.4172/2161-0444.1000206

Copyright: ( 2014 Alwan SM, et al. This is an open-access article distributed under the terms of the Creative Commons Attribution License, which permits unrestricted use, distribution, and reproduction in any medium, provided the original author and source are credited. 


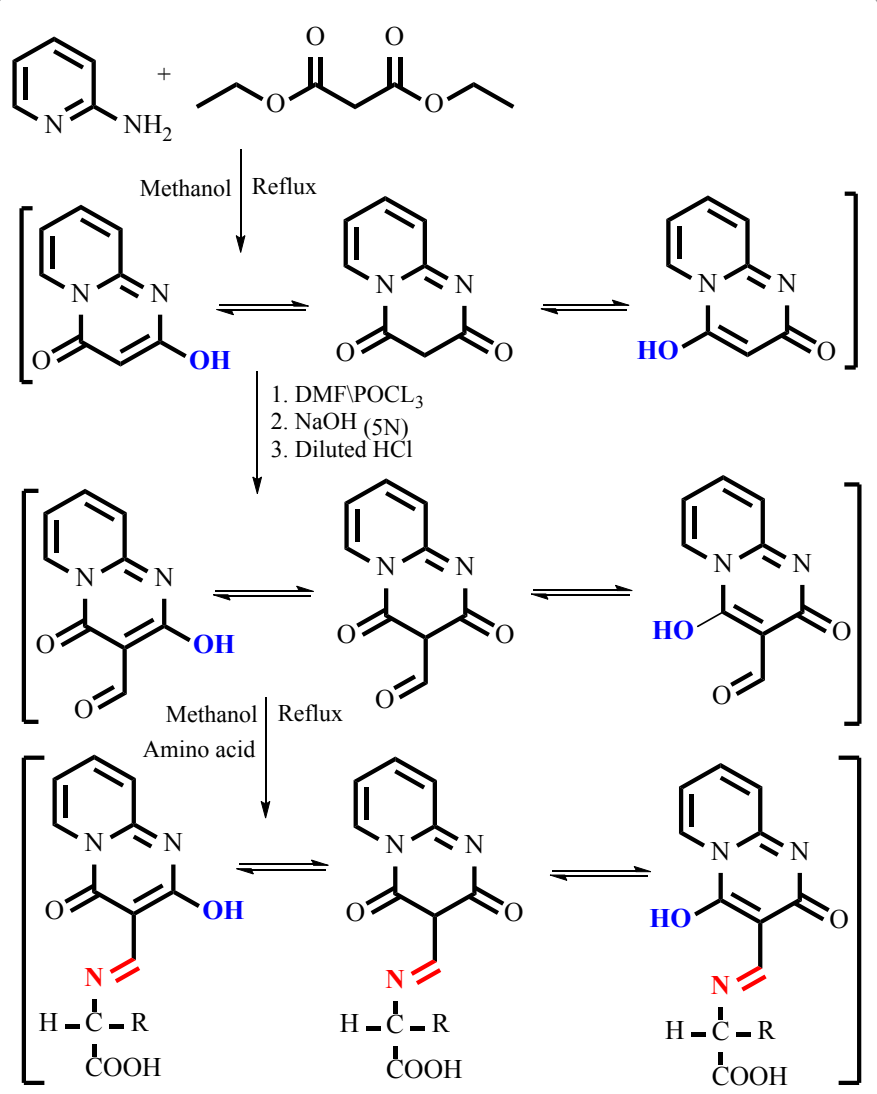

$\mathrm{R}=$ Glycyl (1), Alanyl (2), Valinyl (3), Glutamyl (4), Histidyl (5), tryptophanyl (6)

Scheme 1: Chemical synthesis of compounds 1a, 1b and the Schiff bases.

\section{Chemical synthesis}

a) Synthesis of $2 \mathrm{H}$-pyrido [1, 2-a] pyrimidine-2, $4(3 \mathrm{H})$ dione, $1 \mathrm{a}$

2-aminopyridine $(0.106 \mathrm{M}, 10 \mathrm{~g})$ and diethyl malonate $(0.106 \mathrm{M}$, $21.22 \mathrm{~g}$ ) were suspended in ethanol $(10 \mathrm{~mL})$ and heated under reflux for $6 \mathrm{hrs}$ in a flask fitted with a still head to extract ethanol continuously. The mixture was then cooled and the obtained precipitate was filtered and washed several times with ethanol and dried in an oven at $50{ }^{\circ} \mathrm{C}$. This product was crystallized from hot water to afford compound $1 \mathrm{a}$ [1]. Yield: $85 \%$, white powder, m.p. $298^{\circ} \mathrm{C}$ (decomposed). IR spectra $\left(v, \mathrm{~cm}^{-1}\right) ; 3095$ (C-H of alkene), 2904 (assym. C-H of $\left.-\mathrm{CH}_{2}-\right), 2640-$ 2810 (broad enolic $\mathrm{OH}$ ), $1693(\mathrm{C}=\mathrm{O}$ of $\mathrm{COOH}), 1653(\mathrm{C}=\mathrm{O}$ of amide) and $1618\left(\mathrm{C}=\mathrm{N}\right.$ of imine).The ${ }^{1} \mathrm{H}-\mathrm{NMR}$ spectra (500 MHz, DMSO) $\delta: 3.2\left(2 \mathrm{H}, \mathrm{s}, \mathrm{C}_{3}-\mathrm{CH}_{2}\right), 6.5\left(1 \mathrm{H}, \mathrm{t}, \mathrm{C}_{3}-\mathrm{H}\right) 7.1\left(1 \mathrm{H}, \mathrm{t}, \mathrm{C}_{9}-\mathrm{H}\right.$ pyridine $), 7.4$ $\left(1 \mathrm{H}, \mathrm{t}, \mathrm{C}_{7}-\mathrm{H}\right), 8.1\left(1 \mathrm{H}, \mathrm{t}, \mathrm{C}_{8}-\mathrm{H}\right), 8.9\left(1 \mathrm{H}, \mathrm{t}, \mathrm{C}_{6}-\mathrm{H}\right), 11.9\left(1 \mathrm{H}, \mathrm{s}, \mathrm{C}_{2}-\mathrm{OH}\right)$. Addition of $\mathrm{D}_{2} \mathrm{O}$ to this compound indicated the disappearance of this proton. The elemental microanalysis $(\mathrm{CHN})$ was recorded for $\mathrm{C}_{8} \mathrm{H}_{6} \mathrm{~N}_{2} \mathrm{O}_{2}(162.0)$; Calculated; C: $59.26 ; \mathrm{H}: 3.73 ; \mathrm{N}: 17.28$; Found; $\mathrm{C}$ : 59.6; H: 3.87; N: 16.89 .

b) Synthesis of 3-formyl-2H-pyrido $[1,2 \mathrm{a}]$ pyrimidine-2, $4-(3 \mathrm{H})$ dione, $1 b$

Phosphoryl chloride $(0.032 \mathrm{M}, 3 \mathrm{~mL})$ was added slowly with continuous stirring to the $\mathrm{N}, \mathrm{N}$-dimethylformamide $(30 \mathrm{~mL})$ incubated in an ice bath. Compound $1 \mathrm{a}(0.029 \mathrm{M}, 4.85 \mathrm{~g})$ was added and the mixture was heated on a water bath at $50^{\circ} \mathrm{C}$ for $20 \mathrm{~min}$. The mixture was poured slowly into sodium hydroxide $(5 \mathrm{~N}, 50 \mathrm{~mL})$ with vigorous stirring and ice cubes were added as soon as the reaction became exothermic. The mixture was then acidified to $\mathrm{pH}$ 5.5-6.0 by dilute hydrochloric acid and stored in a refrigerator. A precipitate was collected, washed excessively with distilled water and dried in an oven at $50^{\circ} \mathrm{C}$. This product was crystallized from $\mathrm{N}, \mathrm{N}$-dimethyl formamide to afford compound $1 \mathrm{~b}$. The chemical synthesis is represented in scheme (1). Yield: $50 \%$, yellow powder, m.p. $277^{\circ} \mathrm{C}$ (decomposed). IR spectra $\left(v, \mathrm{~cm}^{-1}\right) ; 3113$ (C-H of alkene), 2773 (C-H of aldehyde), 2640 (broad enolic $\mathrm{OH}), 1732(\mathrm{C}=\mathrm{O}$ of aldehyde), 1654-1680 $(\mathrm{C}=\mathrm{O}$ broad of amides) and 1635 (C=N of imine). The ${ }^{1} \mathrm{H}-\mathrm{NMR}$ spectra $(500$ $\mathrm{MHz}, \mathrm{DMSO}) \delta: 4.1\left(1 \mathrm{H}, \mathrm{s}, \mathrm{C}_{3}-\mathrm{H}\right) 6.5\left(1 \mathrm{H}, \mathrm{t}, \mathrm{C}_{3}-\mathrm{H}\right) 7.1\left(1 \mathrm{H}, \mathrm{t}, \mathrm{C}_{9}-\mathrm{H}\right.$ pyridine), $7.4\left(1 \mathrm{H}, \mathrm{t}, \mathrm{C}_{7}-\mathrm{H}\right), 8.1\left(1 \mathrm{H}, \mathrm{t}, \mathrm{C}_{8}-\mathrm{H}\right), 8.9\left(1 \mathrm{H}, \mathrm{t}, \mathrm{C}_{6}-\mathrm{H}\right), 10.3(1 \mathrm{H}$, $\mathrm{s}, \mathrm{C}_{3}-\mathrm{H}$ aldehyde), $11.9\left(1 \mathrm{H}, \mathrm{s}, \mathrm{C}_{2}-\mathrm{OH}\right)$. Addition of $\mathrm{D}_{2} \mathrm{O}$ to compound $1 \mathrm{~b}$ displayed no proton at this $\mathrm{C}_{2}-\mathrm{OH}$. The elemental microanalysis (CHN) was recorded for $\mathrm{C}_{9} \mathrm{H}_{6} \mathrm{~N}_{2} \mathrm{O}_{3}$ (190.2); Calculated; C: $56.85 ; \mathrm{H}$ : 3.18; N: 14.73; Found; C: 56.91; H: 3.22; N: 14.96.

c) General procedure for the synthesis of Schiff bases of 3-formyl-2H-pyrido [1,2a] pyrimidine-2, 4- $(3 \mathrm{H})$ dione with certain amino acids, 1-6

Schiff bases of 3-formyl-2H-pyrido [1,2-a] pyrimidine-2,4- $(3 \mathrm{H})$ dione $1 \mathrm{~b}$ with certain amino acids were synthesized according to the reported method [18] and as described below.

A mixture of compound $1 \mathrm{~b}(5.2 \mathrm{mM})$ and the amino acid $(5.2$ $\mathrm{mM})$ in dry methanol $(20 \mathrm{~mL})$ containing a catalytic amount of glacial acetic acid $(0.5 \mathrm{~mL})$ were reacted under reflux for $4 \mathrm{hrs}$. The unreacted compound $1 \mathrm{~b}$ and the amino acid were separated by dissolving in hot water. The product was crystallized from hot ethanol. The chemical syntheses of compounds 1-6 are illustrated on scheme 1 .

d) Synthesis of the Schiff base of 3-formyl-2H-pyrido [1, 2-a] pyrimidine-2, 4-(3H) dione with glycine, 1

2-((2,4-dioxo-3,4-dihydro-2H-pyrido[1,2-a]pyrimidine-3-yl) methylene amino) acetic acid.

Compound $1 \mathrm{~b}(5.2 \mathrm{mM}, 1 \mathrm{~g})$ in dry methanol $(20 \mathrm{~mL})$ was reacted with glycine $(5.2 \mathrm{mM}, 0.39 \mathrm{~g})$ suspended in methanol $(10 \mathrm{~mL})$ containing glacial acetic acid $(0.5 \mathrm{~mL})$ and the mixture was refluxed for $4 \mathrm{hrs}$. The mixture turned to an orange solution, which was cooled in a refrigerator and an orange precipitate was collected, washed thoroughly with hot water to remove unreacted materials (compound $1 \mathrm{~b}$ and glycine). The orange product was triturated with petroleum ether $(2 \times$ $20 \mathrm{~mL}$ ) and was dried in an oven at $50^{\circ} \mathrm{C}$. Yield: $65 \%$, pink powder, m.p. $220^{\circ} \mathrm{C}$ (dec.). IR spectra $\left(v, \mathrm{~cm}^{-1}\right) ; 3097(\mathrm{C}=\mathrm{H}$, aromatic), 2970, 2920 (C-H), 3000-2800 (keto-enol OH), $1668(\mathrm{C}=\mathrm{O}), 1631(\mathrm{C}=\mathrm{N}) .{ }^{1} \mathrm{H}-\mathrm{NMR}$ (500 MHz, DMSO) $\delta: 3.5\left(1 \mathrm{H}, \mathrm{s}\right.$, enolic $\left.\mathrm{C}_{2}-\mathrm{OH}\right), 4.45\left(2 \mathrm{H}, \mathrm{s},-\mathrm{CH}_{2}-\right)$, $6.85\left(1 \mathrm{H}, \mathrm{t}, \mathrm{C}_{9}-\mathrm{H}\right.$ pyridine), $7.1\left(1 \mathrm{H}, \mathrm{t}, \mathrm{C}_{8}-\mathrm{H}\right.$ pyridine), $7.8\left(1 \mathrm{H}, \mathrm{t}, \mathrm{C}_{7}-\mathrm{H}\right)$, $8.6\left(1 \mathrm{H}, \mathrm{d}, \mathrm{C}_{6}-\mathrm{H}\right), 8.7(1 \mathrm{H}, \mathrm{s}, \mathrm{N}=\mathrm{CH}-), 10(1 \mathrm{H}, \mathrm{s}, \mathrm{COOH})$. The $\mathrm{CHN}$ analysis was recorded for $\mathrm{C}_{8} \mathrm{H}_{6} \mathrm{~N}_{2} \mathrm{O}_{2}$ (247.2); Calculated; C: $59.26 ; \mathrm{H}$ : 3.73; N: 17.28. Found; C: 59.60, H: 3.86; N: 16.49 .

e) Synthesis of the Schiff base of 3-formyl-2H-pyrido [1, 2-a] pyrimidine-2,4- $(3 \mathrm{H})$ dione with alanine, 2

2-((2,4-dioxo-3,4-dihydro-2H-pyrido[1,2-a]pyrimidine-3-yl) methyleneamino) propanoic acid.

Compound $1 \mathrm{~b}(5.2 \mathrm{mM}, 1 \mathrm{~g})$ in dry methanol $(20 \mathrm{~mL})$ was reacted with alanine $(5.2 \mathrm{mM}, 0.463 \mathrm{~g})$ suspended in methanol $(10 \mathrm{~mL})$ and the procedure was continued as previously described. Yield: $47 \%$, orange powder, m.p. $152^{\circ} \mathrm{C}$. IR spectra $\left(\boldsymbol{v}, \mathrm{cm}^{-1}\right) ; 3096(\mathrm{C}-\mathrm{H}), 2970$, $2920(\mathrm{C}-\mathrm{H}), 3000-2800(\mathrm{OH}), 1674(\mathrm{C}=\mathrm{O}), 1618(\mathrm{C}=\mathrm{N}) .{ }^{1} \mathrm{H}-\mathrm{NMR}(500$ $\mathrm{MHz}, \mathrm{DMSO}) \delta: 1.5\left(3 \mathrm{H}, \mathrm{d}, \mathrm{CH}_{3}\right), 3.5(1 \mathrm{H}, \mathrm{m},=\mathrm{N}-\mathrm{CH}-), 4.4(1 \mathrm{H}, \mathrm{s}$, $\left.\mathrm{C}_{2}-\mathrm{OH}\right), 6.9\left(1 \mathrm{H}, \mathrm{t}, \mathrm{C}_{9}-\mathrm{H}\right), 7.7\left(1 \mathrm{H}, \mathrm{d}, \mathrm{C}_{8}-\mathrm{H}\right), 8.1\left(1 \mathrm{H}, \mathrm{t}, \mathrm{C}_{7}-\mathrm{H}\right), 8.5(1 \mathrm{H}, \mathrm{d}$, 
$\left.\mathrm{C}_{6}-\mathrm{H}\right), 8.7(1 \mathrm{H}, \mathrm{s},-\mathrm{CH}-\mathrm{N}=), 11.2(1 \mathrm{H}, \mathrm{s}, \mathrm{COOH})$. The $\mathrm{CHN}$ analysis was recorded for $\mathrm{C}_{9} \mathrm{H}_{6} \mathrm{~N}_{2} \mathrm{O}_{3}(261.2)$; Calculated; $\mathrm{C}: 56.86 ; \mathrm{H}: 3.18 ; \mathrm{N}: 14.73$. Found: C: $56.91 ; \mathrm{H}: 3.22 ; \mathrm{N}: 14.96$.

f) Synthesis of the Schiff base of 3-formyl-2H-pyrido [1, 2-a] pyrimidine-2,4-(3H) dione with leucine, 3

2-((2,4-dioxo-3,4-dihydro-2H-pyrido[1,2-a]pyrimidine-3-yl) methyleneamino)-3-methyl butanoic acid.

Compound $1 \mathrm{~b}(5.2 \mathrm{mM}, 1 \mathrm{~g})$ in dry methanol $(20 \mathrm{~mL})$ was reacted with leucine $(5.2 \mathrm{mM}, 0.608 \mathrm{~g}$ ) suspended in methanol and was treated as previously described. Yield: $77 \%$, orange powder, m.p. $136-138^{\circ} \mathrm{C}$. IR spectra $\left(\boldsymbol{v}, \mathrm{cm}^{-1}\right) ; 3080,3040(\mathrm{C}-\mathrm{H}), 2955(\mathrm{C}-\mathrm{H}), 3000-2800(\mathrm{OH})$, $1676(\mathrm{C}=\mathrm{O}), 1618(\mathrm{C}=\mathrm{N}) .{ }^{1} \mathrm{H}-\mathrm{NMR}(500 \mathrm{MHz}, \mathrm{DMSO}) \delta: 0.9(3 \mathrm{H}$, d, $\left.\mathrm{CH}_{3}\right), 3.5(1 \mathrm{H}, \mathrm{d},=\mathrm{N}-\mathrm{CH}-), 3.6\left(1 \mathrm{H}, \mathrm{s}, \mathrm{C}_{2}-\mathrm{OH}\right), 3.8\left(6 \mathrm{H}, \mathrm{m}, \mathrm{CH}_{3}-\mathrm{C}-\right.$ $\left.\mathrm{CH}_{3}\right), 7.1\left(1 \mathrm{H}, \mathrm{t}, \mathrm{C}_{9}-\mathrm{H}\right), 7.7\left(1 \mathrm{H}, \mathrm{d}, \mathrm{C}_{8}-\mathrm{H}\right), 8.1\left(1 \mathrm{H}, \mathrm{t}, \mathrm{C}_{7}-\mathrm{H}\right), 8.2(1 \mathrm{H}$, d, $\left.\mathrm{C}_{6}-\mathrm{H}\right), 8.4(1 \mathrm{H}, \mathrm{s}, \mathrm{N}=\mathrm{CH}-), 11.2(1 \mathrm{H}, \mathrm{s}, \mathrm{COOH})$. The $\mathrm{CHN}$ analysis was recorded for $\mathrm{C}_{15} \mathrm{H}_{17} \mathrm{~N}_{3} \mathrm{O}_{4}$ (303.3); Calculated; C: $59.40 ; \mathrm{H}: 5.65 ; \mathrm{N}$ : 13.85. Found; C: $58.65 ; \mathrm{H}: 5.95 ; \mathrm{N}: 14.24$.

g) Synthesis of the Schiff base of 3-formyl-2H-pyrido [1, 2-a] pyrimidine-2, $4-(3 \mathrm{H})$ dione with glutamic acid, 4

2-((2,4-dioxo-3,4-dihydro-2H-pyrido[1,2-a]pyrimidine-3-yl) methyleneamino)-3-methyl succinic acid.

Compound $1 \mathrm{~b}(5.2 \mathrm{mM}, 1 \mathrm{~g})$ in dry methanol $(20 \mathrm{~mL})$ was reacted with glutamic acid ( $5.2 \mathrm{mM}, 0.765 \mathrm{~g}$ ), as previously described. Yellow product was collected and washed with hot ethanol $(3 \times 10 \mathrm{~mL})$ and was dried in an oven at $50^{\circ} \mathrm{C}$ to afford compound 4 . Yield: $41 \%$, yellowish brown, m.p. $212^{\circ} \mathrm{C}$ (dec.). IR spectra $\left(\boldsymbol{v}, \mathrm{cm}^{-1}\right) ; 3078,3030(\mathrm{C}-\mathrm{H}) 3000-$ $2800(\mathrm{OH}), 2935,2840(\mathrm{C}-\mathrm{H}) 1693(\mathrm{C}=\mathrm{O}), 1639(\mathrm{C}=\mathrm{O}), 1614(\mathrm{C}=\mathrm{N})$. ${ }^{1} \mathrm{H}-\mathrm{NMR}(500 \mathrm{MHz}, \mathrm{DMSO}) \delta: 2.3\left(2 \mathrm{H}, \mathrm{m},-\mathrm{CH}_{2}-\right), 2.6\left(2 \mathrm{H}, \mathrm{t},-\mathrm{CH}_{2}-\right)$, $3.6\left(1 \mathrm{H}, \mathrm{s}, \mathrm{C}_{2}-\mathrm{OH}\right), 4.6(2 \mathrm{H}, \mathrm{s},=\mathrm{N}-\mathrm{CH}-), 6.9\left(1 \mathrm{H}, \mathrm{t}, \mathrm{C}_{9}-\mathrm{H}\right), 7.1\left(1 \mathrm{H}, \mathrm{d}, \mathrm{C}_{8}-\right.$ $\mathrm{H}), 7.7\left(1 \mathrm{H}, \mathrm{t}, \mathrm{C}_{7}-\mathrm{H}\right), 8.5\left(1 \mathrm{H}, \mathrm{d}, \mathrm{C}_{6}-\mathrm{H}\right), 8.6(1 \mathrm{H}, \mathrm{s}, \mathrm{N}=\mathrm{CH}-), 11.2(1 \mathrm{H}$, $\mathrm{s}, \mathrm{COOH}), 12.4(1 \mathrm{H}, \mathrm{s}, \mathrm{COOH})$. The $\mathrm{CHN}$ analysis was recorded for $\mathrm{C}_{14} \mathrm{H}_{13} \mathrm{~N}_{3} \mathrm{O}_{6}$ (319.3); Calculated; C: 52.67; H: 4.10; N: 13.16. Found; C: 54.77; H: 3.23; N: 12.91.

h) Synthesis of the Schiff base of 3-formyl-2H-pyrido [1, 2-a] pyrimidine-2,4- $(3 \mathrm{H})$ dione with histidine, 5

2-((2,4-dioxo-3,4-dihydro-2H-pyrido[1,2-a]pyrimidine-3-yl) methyleneamino)-3-(1H-imidazol-5-yl) propanoic acid.

Compound $1 \mathrm{~b}(5.2 \mathrm{mM}, 1 \mathrm{~g})$ in dry methanol $(20 \mathrm{~mL})$ containing glacial acetic acid $(0.5 \mathrm{~mL})$ was reacted with histidine $(5.2 \mathrm{mM}$, $0.806 \mathrm{~g}$ ), as previously described. The Schiff base was collected as a yellow precipitate from the methanolic solution. The precipitate was washed with hot water to remove the unreacted materials. Yield: $68 \%$, yellow powder, m.p. $226^{\circ} \mathrm{C}$ (dec.). IR spectra $\left(\boldsymbol{v}, \mathrm{cm}^{-1}\right) ; 3395(\mathrm{~N}-\mathrm{H})$, 3140, $3112(\mathrm{C}-\mathrm{H})$, 3000-2800 (OH), $2950(\mathrm{C}-\mathrm{H}), 1695(\mathrm{C}=\mathrm{O}), 1633$ $(\mathrm{C}=\mathrm{N}) .{ }^{1} \mathrm{H}-\mathrm{NMR}(500 \mathrm{MHz}, \mathrm{DMSO}) \delta: 2.3(2 \mathrm{H}, \mathrm{m},-\mathrm{CH}-$ assym. C of histidine), $2.6\left(2 \mathrm{H}, \mathrm{t},-\mathrm{CH}_{2}-\right), 3.3\left(1 \mathrm{H}, \mathrm{d}, \mathrm{C}_{3}-\mathrm{H}\right), 3.6\left(1 \mathrm{H}, \mathrm{s}, \mathrm{C}_{2}-\mathrm{OH}\right)$, $4.6(1 \mathrm{H}, \mathrm{s},-\mathrm{CH}-\mathrm{N}=), 6.9\left(1 \mathrm{H}, \mathrm{t}, \mathrm{C}_{9}-\mathrm{H}\right), 7.1\left(1 \mathrm{H}, \mathrm{d}, \mathrm{C}_{8}-\mathrm{H}\right), 7.7\left(1 \mathrm{H}, \mathrm{t}, \mathrm{C}_{7}-\right.$ $\mathrm{H}), 7.3\left(1 \mathrm{H}, \mathrm{s},-\mathrm{CH}\right.$ - imidazole ring), $8.5\left(1 \mathrm{H}, \mathrm{d}, \mathrm{C}_{6}-\mathrm{H}\right), 12.4(1 \mathrm{H}, \mathrm{s}$, $\mathrm{COOH}), 13.2(1 \mathrm{H}, \mathrm{s}, \mathrm{NH}$ imidazole). The $\mathrm{CHN}$ analysis was recorded for $\mathrm{C}_{15} \mathrm{H}_{13} \mathrm{~N}_{5} \mathrm{O}_{4}$ (327.3); Calculated; C: 55.05; H: 4.00; N: 21.40. Found; C: $56.47 ; \mathrm{H}: 4.15 ; \mathrm{N}: 21.63$.

i) Synthesis of the Schiff base of 3-formyl-2H-pyrido [1, 2-a pyrimidine-2,4-(3H) dione with tryptophan, 6

2-((2,4-dioxo-3,4-dihydro-2H-pyrido[1,2-a]pyrimidine-3-yl) methyleneamino)-2-(1H-indol-3-yl) acetic acid.

A similar procedure was conducted to produce compound 6 , by using the followings compound $1 \mathrm{~b}(5.2 \mathrm{mM}, 1 \mathrm{~g})$ in dry methanol $(20$ $\mathrm{mL})$ containing glacial acetic acid $(0.5 \mathrm{~mL})$ and tryptophan $(5.2 \mathrm{mM}$, $1.061 \mathrm{~g})$. The Schiff base was collected as a yellow precipitate from the methanolic solution and was washed with hot water to remove unreacted materials. The precipitate was triturated with petroleum ether $(2 \times 20 \mathrm{~mL})$ and dried in an oven at $50^{\circ} \mathrm{C}$. Yield: $72 \%$, yellow powder, m.p. $205^{\circ} \mathrm{C}$ (dec.). IR spectra $\left(v, \mathrm{~cm}^{-1}\right) ; 3404(\mathrm{~N}-\mathrm{H}$, indole), 3191, $3136(\mathrm{C}-\mathrm{H})$, 3000-2800 (OH), 2950, $2835(\mathrm{C}-\mathrm{H}), 1724(\mathrm{C}=\mathrm{O})$, 1658, $1641(\mathrm{C}=\mathrm{N}), 1626(\mathrm{~N}-\mathrm{H}) .{ }^{1} \mathrm{H}-\mathrm{NMR}(500 \mathrm{MHz}, \mathrm{DMSO}) \delta: 2.3$ $\left(1 \mathrm{H}, \mathrm{m},-\mathrm{CH}-\right.$ assym. C of tryptophan), $2.6\left(2 \mathrm{H}, \mathrm{t},-\mathrm{CH}_{2}-\right), 3.3(1 \mathrm{H}$, s, $\left.\mathrm{C}_{3}-\mathrm{H}\right), 7.1,7.4,8.1$ and $8.9\left(1 \mathrm{H}, \mathrm{d}, \mathrm{C}_{9}-\mathrm{H}\right.$ to $\mathrm{C}_{6}-\mathrm{H}$ pyridine $), 7.1-7.6$ $(1 \mathrm{H}, \mathrm{s}, \mathrm{CH}$ aromatic), $10.8(1 \mathrm{H}, \mathrm{s}, \mathrm{NH}$ indole), $12.4(1 \mathrm{H}, \mathrm{s}, \mathrm{COOH})$. The CHN analysis was recorded for $\mathrm{C}_{20} \mathrm{H}_{16} \mathrm{~N}_{4} \mathrm{O}_{4}$ (376.4); Calculated; $\mathrm{C}$ : 63.82; H: 4.28; N: 14.89. Found; C: 65.90; H: 4.26; N: 14.66.

\section{Results}

\section{Spectroscopic characterization of the synthesized compounds}

IR spectra: The IR spectra of the intermediates and the new derivatives showed the appearance of bands at 3020-3095 cm-1 for the enolic $\mathrm{OH}$ absorbance in all compounds. The bands at $1720 \mathrm{~cm}^{-1}$ and $1693 \mathrm{~cm}^{-1}$ are good indication for the carbonyl of the cyclic amides at $\left(\mathrm{C}_{4}-\mathrm{N}_{5}\right)$ and $\left(\mathrm{N}_{1}-\mathrm{C}_{2}\right)$ respectively. The characteristic bands (1618-1635 $\mathrm{cm}^{-1}$ ) of imines in compounds 1-6 represent the Schiff bases formed with amino acids. The presence of $\mathrm{NH}$ absorption band at 3210$3050 \mathrm{~cm}^{-1}$ in compounds 1-6 indicated that there is a tautomerism between the imine group and the pyrimidine ring. The IR spectrum of compound 1a showed an absorption band at $1720 \mathrm{~cm}^{-1}$ and $1693 \mathrm{~cm}^{-1}$ for the carbonyl of the cyclic amides at $\left(\mathrm{C}_{4}-\mathrm{N}_{5}\right)$ and $\left(\mathrm{N}_{1}-\mathrm{C}_{2}\right)$ respectively. $\mathrm{A}$ band at $1618 \mathrm{~cm}^{-1}$ for $\mathrm{C}=\mathrm{N}$ - stretching of imine group. An absorption band was shown at $3020-3095 \mathrm{~cm}^{-1}$ for broad enolic $\mathrm{OH}$ group. This characteristic band is clear evidence of the keto-enol tautomerism between the carbonyl and $\mathrm{OH}$ groups at $\mathrm{C}_{2}$ and $\mathrm{C}_{3}$ of the pyrimidine ring. $\mathrm{C}-\mathrm{H}$ stretching of the corresponding aldehyde $1 \mathrm{~b}$ appeared at $1392 \mathrm{~cm}^{-1}$, while the carbonyl of $1 \mathrm{~b}$ appeared at $1732 \mathrm{~cm}^{-1}$.

${ }^{1} \mathrm{H}-\mathrm{NMR}$ spectra: The ${ }^{1} \mathrm{H}-\mathrm{NMR}$ spectral data of compounds 1a and $1 \mathrm{~b}$ displayed characteristic protons of the pyridine nucleus of pyridopyrimidine $\left(\mathrm{C}_{6}-\mathrm{C}_{9}\right)$ and the protons of the two methylene groups at 6.85. 1-6 displayed the characteristic peaks at $\mathrm{C}_{6}-\mathrm{C}_{9}$ of the pyridine ring appeared at 8.6, 7.8, 7.1 and 6.85 respectively. The imine protons present in compounds 1-6 was observed and appeared as singlet at $\delta$ 8.4-8.7. Proton of $\mathrm{OH}$ of the keto-enol form for all compounds appeared at range of $\delta 3.5-4.4$. Addition of $\mathrm{D}_{2} \mathrm{O}$ to compounds $1 \mathrm{a}$ and $1 \mathrm{~b}$ showed disappearance of protons in the ${ }^{1} \mathrm{H}-\mathrm{NMR}$ spectra. This is a further confirmation of the existence of keto-enol form. Protons of $\mathrm{COOH}$ for compounds 1-3 and 5-6 appeared weak at 11.2, while the proton of the second carboxyl of glutamic acid in compound 4 also appeared weak at 12.4 .

Elemental microanalysis (CHN): The elemental microanalyses of the starting materials compounds $1 \mathrm{a}$ and $1 \mathrm{~b}$ and the target compounds 1-6 confirmed their chemical structures and were within the acceptable range.

Tautomerism phenomenon of the synthesized compounds: For compounds $1 \mathrm{a}$ and $1 \mathrm{~b}$, depending on solution, two possible conformations can be described and these are the keto-enol forms, as shown on schemes 1 . The chemical structures of $1 \mathrm{a}$ is assigned as $4 \mathrm{H}$-pyrido [1, 2-a] pyrimidine-2-hydroxy-4-one or $4 \mathrm{H}$-pyrido [1,2a] pyrimidine-4-hydroxy-2-one and these were confirmed by spectral analysis. Compounds 1-6 may also undergo further tautomerism leading to few new situations, as shown on schemes 1 and 2. These forms showed the appearance of the imine group and at the same time 
<smiles>[R]C(N/C=C1/C(=O)N=C2C=CC=CN2C1=O)C(=O)O</smiles>

Scheme 2: Phenomenon of tautomirism of the synthesized Schiff bases.

\begin{tabular}{|c|c|c|c|c|c|c|}
\hline Compound & $\begin{array}{c}\text { Concentration } \\
\mu \mathrm{g} / \mathrm{ml}\end{array}$ & $\begin{array}{l}\text { E. coli } \\
\text { ATCC } \\
29522\end{array}$ & $\begin{array}{c}\text { P. aurug. } \\
\text { ATCC } \\
27853\end{array}$ & $\begin{array}{c}S . \\
\text { aurueus } \\
\text { ATCC } \\
25923\end{array}$ & $\begin{array}{l}\text { B.Subtilus } \\
\text { ATCC } 6633\end{array}$ & C.Albicans \\
\hline \multirow{2}{*}{1} & 50 & + & + & + & - & - \\
\hline & 100 & + & + & ++ & - & + \\
\hline \multirow{2}{*}{2} & 50 & + & + & - & - & - \\
\hline & 100 & ++ & + & - & - & + \\
\hline \multirow{2}{*}{3} & 50 & - & + & - & - & - \\
\hline & 100 & + & ++ & - & - & - \\
\hline \multirow{2}{*}{4} & 50 & ++ & + & + & + & ++ \\
\hline & 100 & +++ & ++ & - & - & - \\
\hline \multirow{2}{*}{5} & 50 & + & ++ & - & - & + \\
\hline & 100 & +++ & +++ & - & - & ++ \\
\hline \multirow{2}{*}{6} & 50 & ++ & ++ & + & - & - \\
\hline & 100 & +++ & ++ & ++ & ++ & ++ \\
\hline \multirow{2}{*}{ Std.1 } & 50 & +++ & ++ & ++ & ++ & - \\
\hline & 100 & +++ & +++ & +++ & +++ & - \\
\hline \multirow{2}{*}{ Std.2 } & 50 & ++ & +++ & ++ & ++ & - \\
\hline & 100 & +++ & +++ & ++ & ++ & - \\
\hline \multirow{2}{*}{ Std.3 } & 50 & - & - & - & - & ++ \\
\hline & 100 & - & - & - & - & +++ \\
\hline
\end{tabular}

Key to symbols:- $=$ no inhibition, $+=14 \mathrm{~mm},++=15-17 \mathrm{~mm},+++=$ more than $18 \mathrm{~mm}$.

Std. 1 = Ceftriaxone, Std. 2 = Amoxicillin, Std. 3 = Fluconazole

Table 1: Antimicrobial activity of compounds [1-6].

hydroxyl group and the presence of - NH due to tautomerism with the pyridopyrimidine nucleus. These groupings appeared on the IR spectra of compounds 1-6, which have supported this phenomenon.

\section{Discussion}

The IR spectra of the new derivatives helped to confirm their chemical structures and their tautomeric forms by showing the ketoenol forms. It was reported that such tautomeric forms were observed in the synthesis of compounds $1 \mathrm{a}$ and $1 \mathrm{~b}$ [22]. This situation was also previously observed for synthesis of pyridopyrimidine derivatives [2326]. For compounds 1-6, there are even further tautomeric forms that are formed between $\mathrm{C}_{2}-\mathrm{C}_{4}$ and at $\mathrm{C}_{3}$ and the imine formed with the amino acids (scheme 2). This tautomerism is governed by the bonds illustrated to include major changes on the molecules and cannot be ruled out. The main differences between these tautomeric forms lie in the intramolecular hydrogen bonding and the relative orientation of the carbonyl groups. Attractive intermolecular interactions occur in this part of the molecule and are responsible for the value of the dihedral angles. These factors have direct impact on the bioactivity of these compounds. This explanation may comply with the observation of the activities of related pyridopyrimidine derivatives $[25,26]$. The presence of an asymmetric center in the amino acid moiety (scheme
2) adds another factor, which is the existence of isomers and this will definitely affect the bioactivity. The ${ }^{1} \mathrm{H}-\mathrm{NMR}$ spectra of the compounds under study 1-6 revealed that their characteristic peaks experienced noticeable changes. The $\mathrm{C}_{9}$ proton experienced deshielding due to the only inductive effect of the $(=\mathrm{N}-\mathrm{C}=\mathrm{O})$ and were recorded downfield as singlet at $\delta 6.85-7.1$. The $\mathrm{C}_{7}$ proton is experiencing less deshielding effect by virtue of its position and nature of bonding. The $\mathrm{C}_{6}$ proton is deshielded due to the inductive effect of $(-\mathrm{N}-\mathrm{C}=\mathrm{O})$ functionality. In all compounds, a very small difference in the chemical shifts of $\mathrm{C}_{6}-\mathrm{C}_{9}$ protons was observed, which is probably due to the small inductive electron withdrawing or donating effects of pyridine or pyrimidine moieties. Similarly, a very small difference in the chemical shifts of the imine protons present in compounds 1-6 was observed and appeared as singlet at $\delta 8.4-8.7$.

\section{Effect of the amino acid moieties}

The newly synthesized compounds 1-6 showed reasonable activities against $P$. auroginosa, B. subtilus, E. coli, S. aurueus and C. albicans. Compounds 1-4 contain two main privileged chemical moieties, Schiff bases with amino acids and pyridopyrimidine, while compounds 5 and 6 contain extra privileged chemical groups and these are the imidazole and indole, respectively. This may be the reason behind the improved antibacterial activities especially against $P$. auroginosa, $C$. albicans and E. coli when compared with the standards used. Similar observation was reported with various types of Schiff bases of such amino acids $[17,18,27]$.

\section{Antimicrobial evaluation}

Generally, all the Schiff bases 1-6 showed good to moderate antibacterial activity against the test microbes (Table 1). Compounds 4- 6 showed also antifungal activity. Compound 5 showed reasonable activity against $p$. aurogenosa and C. albican, while it showed a good activity against $E$. coli and no activity against $\mathrm{G}(-)$ bacteria. Compound 4 showed a moderate activity against $E$. coli and a good activity against Candida. Compounds 2 and 3 had good activity against Candida and a moderate activity against $E$. coli. Compound 1 has a moderate to good activity against all strains, except B.subtilus. However, the Schiff bases of the aromatic amino acids, compounds 5-6 showed better antimicrobial activities compared with those of aliphatic amino acids.

\section{Conclusion}

An interesting approach of using two privileged moieties (Schiff bases of amino acids and pyridopyrimidine ring) is successfully accomplished to produce new pyridopyrimidine derivatives. This approach has afforded new derivatives of reasonable and promising antibacterial activities.

\section{Acknowledgment}

The authors are very grateful to University of Baghdad and College of Pharmacy for supporting this research work.

\section{References}

1. Zoorob HH, HamamaWS (2002) Chemistry of bicyclic pyridines containing a ring-junction nitrogen. Tetrahedron 58: 6143-6162.

2. Katritzky AR, Rogers JW, Witek RM, Nair SK (2011) Synthesis of novel pyrido[,2-a]pyrimidinium tetrafluoroborates. ARKIVOC 2: 297-309.

3. Khan BU (1997) Brief report: risperidone for severely disturbed behavior and tardive dyskinesia in developmentally disabled adults. J Autism Dev Disord 27: 479-489.

4. Jeste DV, Okamoto A, Napolitano J, Kane JM, Martinez RA (2000) Low incidence of persistent tardive dyskinesia in elderly patients with dementia treated with risperidone. Am J Psychiatry 157: 1150-1155. 
Citation: Alwan SM, Al-Kaabi JAS, Hashim RMM (2014) Synthesis and Preliminary Antimicrobial Activity of New Schiff Bases of Pyrido [1,2-a] Pyrimidine Derivatives with Certain Amino Acids. Med chem 4: 635-639. doi:10.4172/2161-0444.1000206

5. Kapui Z, Varga M, Urban-Szabo K, Mikus E, Szabo T, et al. (2003) Biochemical and pharmacological characterization of 2-(9-(2-piperidinoethoxy)-4-oxo$4 \mathrm{H}$-pyrido[,2-a]pyrimidin-2-yloxymethyl)-4-(1-methylethyl)-6-methoxy-,2benzisothiazol-3(2H)-one-,1-dioxide (SSR69071), a novel orally active elastase inhibitor. J Pharmacol Exp Ther 2: 451-459.

6. Awouters F, Vermeire J, Smeyers F, Vermote P, van Beek (1986) Oral antiallergic activity in ascaris hypersensitive dogs: A study of known antihistamines and of the new compounds ramastine (R 57 959) and levocabastine (R 50 547). Drug Development Research 8: 95-102.

7. Motta CL, Sartini S, Mugnaini L, Simorini F, Taliani S, et al. (2007) Pyrido[,2-a] pyrimidin-4-one derivatives as a novel class of selective aldose reductase inhibitors exhibiting antioxidant activity. J Med Chem 4: 4917-4927.

8. Ferrarini PL, Mori C, Armani G, Rossi L (1995) Synthesis of some 4H-pyrido[,2-a] pyrimidin-4-ones investigated as antimicrobial agents. Farmaco 50: 69-72.

9. Hossain N, Rozenski J, De Clercq E, Herdewijn P (1997) Synthesis and Antiviral Activity of the alpha-Analogues of ,5-Anhydrohexitol Nucleosides (,5-Anhydro2,3-dideoxy-D-ribohexitol Nucleosides). J Org Chem 62: 2442-2447.

10. Yao P, Zhai X, Liu D, Qi BH, Tan HL, et al. (2010) Synthesis and antiproliferative activity of novel diaryl ureas possessing a $4 \mathrm{H}$-pyrido[,2-a]pyrimidin-4-one group. Arch Pharm (Weinheim) 343: 17-23.

11. Joseph S, Burke JM (1993) Optimization of an anti-HIV hairpin ribozyme by in vitro selection. J Biol Chem 268: 24515-24518.

12. Raghunath BT, Bhausaheb KG, Muddassar AK, Shivaraj PP, Madhukar N (2008) New Approach for the Synthesis of Pyrido[,2-a]pyrimidines. Scholarly Research Exchange 5-8.

13. Jasinski JP, Butcher RJ, Hakim Al-Arique QN, Yathirajan HS, Narayana B (2009) 3-(2-Chloro-ethyl)-2-methyl-4-oxo-4H-pyrido[,2-a]pyrimidinium 2,4,6-trinitro-phenolate. Acta Crystallogr Sect E Struct Rep Online 65: 02201-2202.

14. Goodacre SC, Street LJ, Hallett DJ, Crawforth JM, Kelly S, et al. (2006) Imidazo[,2-a]pyrimidines as functionally selective and orally bioavailable GABA(A)alpha2/alpha3 binding site agonists for the treatment of anxiety disorders. J Med Chem 49: 35-38.

15. Bishnoi A, Akstk SS (2013) Synthesis, characterization and biological activity of new cyclization products of 3-(4-substituted benzylidene)-2H-pyrido[,2-a] pyrimidine-2,4- (3H)-dione. J Chem Sci 125: 305-312.
16. George T, Kaul CL, Grewal RS, Tahilramani R (1971) Antihypertensive and monoamine oxidase inhibitory activity of some derivatives of 3-formyl-4-oxo4H-pyrido (,2-a) pyrimidine. J Med Chem 14: 913-915.

17. Sakiyan I, Loğoğlu E, Arslan S, Sari N, Sakiyan N (2004) Antimicrobial activities of $\mathrm{N}$-(2-hydroxy-1-naphthalidene)-aminoacid(glycine, alanine, phenylalanine, histidine, tryptophane) Schiff bases and their manganese(III) complexes. BioMetals 17: 115-120.

18. Nursen Sari Saelais. Antibacterial Activities of Some New Amino Acid-Schiff Bases. G.U. journal of science. 2003; 16: 283-288.

19. Gullu M, Razack LA, Utley JHP (1991) Electro-organic Reaction part 35. Effcient Carbon-Oxygen Bond formation in the Anodic Coupling of Pyridopyrimidine Derivatives. Tetrahydron 47: 675-684.

20. Eldredge H, Mee CD, Inventors J, Randolf D, Assignee J (1972) Intermediates and the preparation and use thereof. USA patent 3,674,782.

21. Muhammad AA, Karamat MA (2011) Synthesis, Characterization and Biological activity of Schiff bases. International proceedings on Chemical, biological and enviromental engineering, 10: 1- 7 .

22. Tschitschibabin AE (1924) Formation of bicyclic derivatives of a-aminopyridines Ber Dtsch Chem Ges 57: 1168.

23. Hermecz I, Horvath A, Meszaros Z, De Vos C, Rodriguez L (1984) Nitrogen bridgehead compounds. 44 . New antiallergic $4 \mathrm{H}$-pyrido[,2-a]pyrimidin-4-ones. 4. J Med Chem 27: 1253-1259.

24. Shur M, Israeltam SS (1968) The reaction of amino heterocycles with reactive esters I. Aminopyridines. J Org Chem 33: 3015.

25. Hamdouchi C, Ezquerra J, Vega JA, Vaquero JJ, Alvarez-Builla J, et al. (1999) Short synthesis and anti-rhinoviral activity of imidazo[,2-a]pyridines: the effect of acyl groups at 3-position. Bioorg Med Chem Lett 9: 1391-1394.

26. Rauf A, Liaqat S, Qureshi AM, Yaqub M, Rehman AU, et al. (2012) Synthesis characterization and urease inhibition of 5-substituted-8-methyl-2H-pyrido [,2a] pyrimidine-2,4-(3H)-diones. Med Chem Res 2: 60-74.

27. Evans BE, Rittle KE, Bock MG, DiPardo RM, Freidinger RM, et al. (1988) Methods for drug discovery: development of potent, selective, orally effective cholecystokinin antagonists. J Med Chem 31: 2235-2246. 